\title{
PENGARUH PENGGUNAAN BERBAGAI MACAM VARIETAS MANGGA TERHADAP KUALITAS NATA DE MANGO
}

\author{
INFLUENCE OF MANGOES VARIETIES \\ ON THE QUALITY OF NATA DE MANGO
}

\author{
Frengki Saputra ${ }^{1}$, Rahma Hidaiyanti ${ }^{1}$ \\ ${ }^{1)}$ Program Studi Teknologi Pertanian Fakultas Pertanian UNIVED
}

\begin{abstract}
ABSTRAK
Mangga (Mangifera indical L) pada saat musim panen tiba jumlahnya melimpah ruah, sehingga prospek penjualannya mengalami penurunan harga. Salah satu alternatif pengolahan buah mangga adalah dengan mengolahnya menjadi suatu produk yaitu nata de mango. Nata merupakan makanan berbentuk gel (agar-agar) dengan tekstur agak kenyal, putih dan transparan (menyerupai kolang-kaling). Tujuan penelitian ini untuk mengkarakterisasi pengaruh penggunaan berbagai macam varietas mangga terhadap kualitas nata de mango. Analisa dalam penelitian ini meliputi analisa kadar serat, tekstur dan uji organoleptik (warna, rasa dan tekstur) nata de mango. Hasil analisa kadar serat pada nata de manggo menunjukkan bahwa dari perlakuan jenis mangga yang digunakan dalam penggolahan nata de manggo kandungan serat berkisar antara 1,43\% hingga 2,35\%. Hasil analisa tekstur nata de manggo dengan angka 73,00 mm hingga 102, $67 \mathrm{~mm}$ dan berdasarkan hasil uji organoleptik terhadap rasa, warna dan tekstur bahwa dari perlakuan jenis mangga yang digunakan menunjukan perbedaan yang nyata.
\end{abstract}

Kata kunci : Mangga, Nata, Nata de Mango

\section{ABSTRACT}

Mango (Mangifera indical L) during the harvest season arrives abundant in number, so the prospect of declining sales prices, one mango fruit processing alternative is to process it into a type of nata de mango products. Nata is a food gel (gelatin) with a slightly chewy texture, white and transparent (resembling fro). The purpose of this study on the effect of the use of various varieties of mangoes on the quality of nata de mango. the analysis in this study includes the analysis of fiber content, texture and organoleptic (color, taste, texture dam) nata de mango. the results of the analysis of the fiber content of nata de manggo showed that mango types of treatment used in penggolahan nata de manggo fiber content ranges from $1.43 \%$ to $2.35 \%$, the results of texture analysis nata de manggo with numbers up to $10273.00 \mathrm{~mm}, 67 \mathrm{~mm}$ and based on the results of organoleptic test of flavor, color and texture that the type of treatment used mango shows a noticeable difference.

Keywords: Mango, Nata, Nata de Mango

\section{PENDAHULUAN}

Nata merupakan makanan berbentuk gel (agar-agar) dengan tekstur agak kenyal, putih dan transparan (menyerupai kolang- kaling) (Masaoka et all 1993). Nata dihasilkan dari pertumbuhan mikroorganisme Acetobacter xylinum pada media air kelapa, sehingga dikenal 
dengan nama nata de coco

(Sutarminingsi, 2004). Pemberian nama nata disesuaikan dengan substrat pertumbuhan Acetobacter xilinum,. Sehingga ada beberapa nama nata diantaranya nata de pina, yaitu nata yang diperoleh dari sari buah nanas, nata de mango dari sari buah mangga, nata de soya dari limbah tahu, nata de cacao dari limbah kakao dan lain sebagainya.

Mangga (Mangifera indical L) pada saat musim panen tiba jumlahnya melimpah ruah, sehingga prospek penjualannya mengalami penurunan harga. Hal ini disebabkan karena mangga cepat busuk dan dapat dikonsumsi dalam waktu singkat sebagai buah segar, untuk mengatasi terjadinya kelebihan buah mangga pada musim tertentu maka perlu dilakukan pengawetan pengolahan buah mangga. Salah satu alternatif pengolahan buah mangga adalah dengan mengolahnya menjadi nata de mango (Astawan dan Wiyuni, 1991).

Dengan dilakukannya pembuatan nata de mango maka nilai jual mangga akan bertambah sehingga dapat diperoleh keuntungan yang lebih. Selain itu mangga cocok ditanam di daerah Propinsi Bengkulu. Sehingga perlunya penelitian lebih lanjut mengenai beberapa varietas mangga yang cocok untuk diolah menjadi nata.

\section{METODE PENELITIAN}

\section{Bahan dan Alat}

Bahan yang digunakan adalah mangga varietas harumanis, golek indramayu, kweni dan gedong, gula pasir (sukrosa), ammonium sulfat, asam asetat glacial, biakan murni Acetobacter xylinum dan bahan-bahan untuk analisis kimia yaitu $\mathrm{NaOH}, \mathrm{K}_{2} \mathrm{SO}_{4}, \mathrm{H}_{2} \mathrm{SO}_{4}$, dan aquades. Alat yang digunakan adalah pisau, nampan plastik, timbangan, saringan, gelas ukur, blender, kompor, sendok, panci pengaduk, kertas koran, kertas saring, mistar, baskom, lakmus dan alat tulis. Alat yang digunakan dalam analisa yaitu cawan porselin, desikator, penetrometer, dan mesin pengering.

\section{Prosedur Penelitian}

Prosedur penelitian meliputi penghancuran buah, penyaringan, perebusan dengan ditambahkan gula, $\mathrm{Za}$ dan asam asetat, pendinginan 3 jam, penambahan Acetobacter xylinum sebanyak $100 \mathrm{ml}$ dan difermentasi selama 7 hari. Pemanenan, pemotongan dan perendaman dalam air selama 48 jam, dan dicuci bersih. Nata de mango direbus selama 10 menit dan diangkat untuk direbus kembali dengan ditambahakan 150 gram gula dan sirup kemudian 
dianalisis kadar serat kasar, tekstur dan organoleptik (warna, rasa, dan tekstur).

Rancangan percobaan dalam penelitian ini menggunakan experiment model RAL (Racangan Acak Lengkap) dengan 5 perlakuan variasi jenis mangga yaitu mangga indramayu, mangga golek, mangga harumanis, kweni, dan gedong. Variabel yang diamati dalam penelitian ini meliputi analisa kandungan serat kasar, tekstur dan organoleptik (warna, rasa tekstur) nata de mango

\section{HASIL DAN PEMBAHASAN}

\section{Kadar Serat Kasar Nata de Mango}

Hasil penelitian analisis kadar serat kasar nata de mango dengan perlakuan lima jenis mangga yaitu mangga arumanis, mangga golek, mangga indramayu, kweni dan gedong ditampilkan pada tabel 1 . Tabel 1 menunjukkan bahwa kandungan serat nata de mango dengan perlakuan lima jenis mangga dari yang tertinggi hingga yang terendah yaitu mangga gedong 2,35\% , mangga indramayu $2,19 \%$, mangga arumanis $2,01 \%$, mangga kweni $1,65 \%$, dan mangga golek 1,43\%. Buah mangga merupakan media yang baik bagi pertumbuhan Acetobacter xylinum karena mangga memiliki nutrien, selain itu juga mengandung komposisi karbohidrat yang terdiri dari gula total (Astawan, 2004).
Acetobacter xylinum tumbuh pada media yang mengadung gula dan dapat mengubah gula menjadi selulosa, selulosa yang dikeluarkan kedalam media itu berupa benang-benang membentuk jaringan yang terus menebal menjadi lapisan nata (Heryawan, 2004). Kandungan karbohidrat yang terdiri dari gula sederhana pada mangga gedong sebesar 11,20 gr dan mangga indramayu sebesar 14,10 gr lebih tinggi jika dibandingkan dengan kandungan karbohidrat mangga arumanis, kweni dan golek (Heryawan, 2004).

Gula merupakan nutrien atau sumber karbon yang dibutuhkan Acetobacter xylinum akan merubah sebagian glukosa menjadi selulosa yang akan meningkatkan serat kasar atau selulosa yang terbentuk sebagai hasil metabolisme Acetobacter xylinum, serat kasar merupakan hasil perombakan gula pada medium fermentasi oleh aktivitas Acetobacter xylinum (Anastasia dan Eddy, 2008). Acetobacter xylinum mengambil glukosa dari larutan gula, kemudian digabungkan dengan asam lemak membentuk prekursor pada membran sel. Prekursor ini keluar bersama sama enzim yang mempolimerisasikan glukosa menjadi selulosa diluar sel (Gennadios et all, 1994). 
Tabel 1. Hasil Analisa Kadar Serat Kasar Nata de Mango

\begin{tabular}{cc}
\hline Jenis Varitas Mangga & Kadar Serat Nata de Mango (\%) \\
\hline Arumanis & $\mathbf{2 , 0 1}{ }^{\mathbf{b}}$ \\
Gedong & $\mathbf{2 , 3 5}$ \\
Indramayu & $\mathbf{2 , 1 9}$ \\
Golek & $\mathbf{1 , 4 3}^{\mathrm{a}}$ \\
Kweni & $\mathbf{1 , 6 5}^{\mathrm{c}}$ \\
\hline
\end{tabular}

Ket : Angka yang diikuti kode huruf yang berbeda menunjukkan perberbedan nyata pada taraf $5 \%$

\section{Tekstur Nata de Mango}

Sifat fisik bahan dapat mempengaruhi mutu bahan pangan dan tingkat penerimaan konsumen terhadap bahan pangan. Beberapa contoh pengujian sifat fisik bahan adalah penetapan bentuk dan ukuran, pengukuran diameter, kerapatan dan berat jenis, viskositas dan konsistensi, suhu, kekerasan atau tekstur, turbiditas atau kekeruhan dan kejernihan (Soewedo, 1996). Hasil penelitian analisis tekstur nata de mango dengan perlakuan lima jenis mangga yaitu mangga arumanis, mangga gedong, mangga indramayu, golek dan kweni ditampilkan pada tabel 2. Tabel 2 . menunjukkan bahwa terdapat perbedaan yang nyata pada taraf signifikan 5\%. Tekstur nata de mango yang dihasilkan dapat disebabkan oleh kandungan serat nata, pada analisa kandungan serat nata de mango dengan perlakuan penggunaan buah mangga indramayu menunjukkan kandung serat sebesar 2,19\% karena kandungan karbohidrat berupa gula sederhana mangga indramayu sebesar 14,10 gr lebih tinggi jika dibandingkan dengan kandungan karbohidrat mangga lain.

Ketebalan nata dapat dipengaruhi oleh variasi substrat, komposisi bahan, kondisi lingkungan, dan kemampuan Accetobacter xylinum dalam menghasilkan selulosa (Susanti, 2006). Astawan (2004) menyatakan bahwa apabila filtrat nata de mango difermentasi dengan bantuan mikroba Accetobacter xylinum gula pada filtrat tersebut diubah menjadi asam asetat dan benang-benang selulosa, lama kelamaan akan terbentuk suatu masa yang kokoh dan tebal. Selulosa yang terbentuk oleh bakteri Acetobacter xylinum belum terlalu keras sehingga tekstur menjadi kenyal. 
Tabel 2. Hasil Analisa Tekstur Nata de Mango

\begin{tabular}{cc}
\hline Jenis Varitas Mangga & Tekstur Nata de Mango $(\mathbf{m m})$ \\
\hline Arumanis & $\mathbf{9 2 , 3 3}$ \\
Gedong & $\mathbf{7 3 , 0 0}$ \\
Indramayu & $\mathbf{1 0 2 , 6 7 ^ { \mathbf { a } }}$ \\
Golek & $\mathbf{8 2 , 6 7 ^ { \mathrm { c } }}$ \\
Kweni & $\mathbf{8 9 , 6 9}$ \\
\hline
\end{tabular}

Ket : Angka yang diikuti kode huruf yang berbeda menunjukkan perberbedaan nyata pada taraf signifikan5\%

Sifat Organoleptik Warna Nata de Mango

Warna merupakan parameter organoleptik yang penting dalam suatu produk makanan. Warna merupakan parameter pertama yang menentukan tingkat penerimaan konsumen terhadap suatu produk (Kartika dkk, 1988).Hasil analisa data uji organoleptik terhadap warna nata de mango dapat dilihat pada tabel 3 .

Tabel 3 menjelaskan hasil uji organoleptik terhadap warna nata de mango dimana pada perlakuan lima jenis mangga yang digunakan menunjukkan perbedaan yang nyata pada taraf signifikan 5\%. Warna nata de mango yang dihasilkan sesuai SNI No 01-43171996 yaitu normal. Warna nata de mango yang dihasilkan putih keruh. Hal ini dikarenakan warna dipengaruhi oleh tebal nata, semakin tebal nata maka warna yang dihasilkan semakin gelap (putih keruh), sebaliknya semakin tipis nata, warna yang dihasilkan semakin terang (putih jernih). Pada nata yang tebal pembentukan jaringan selulosa semakin banyak dan rapat. Perlakuan jenis mangga arumanis pada uji organoleptik terhadap warna lebih disukai oleh panelis dengan penilaian 4,15 (suka).

Tabel 3. Hasil Rata-rata Uji Organoleptik Warna Nata de Mango

\begin{tabular}{cc}
\hline Jenis Varitas Mangga & Warna Nata de Mango \\
\hline Arumanis & $\mathbf{4 , 1 5}$ \\
Gedong & $\mathbf{4 , 1 0}$ \\
Indramayu & $\mathbf{3 , 7 0}$ \\
Golek & $\mathbf{3 , 6 0}^{\mathbf{b}}$ \\
Kweni & $\mathbf{3 , 5 0}$ \\
\hline
\end{tabular}

Ket : Angka yang diikuti oleh kode huruf yang berbeda menunjukkan adanya perbedaan yang nyata pada taraf signifikansi $5 \%$. Ket Skala : $1=$ sangat tidak suka; $2=$ tidak suka; $3=$ agak suka; $4=$ suka; $5=$ sangat suka 
Sifat Organoleptik Rasa Nata de Mango

Cita rasa merupakan suatu kesan yang diterima melalui saraf indera pengecapan, yaitu lidah. Sebagai hasil hadirnya senyawa-senyawa yang larut dalam air. Secara umum ada lima cita rasa juga digunakan untuk menerangkan mutu dari kesan yang ditimbulkan oleh senyawasenyawa yang ada didalam bahan makanan atau minuman (Kartika dkk, 1988).

Hasil analisa data uji organoleptik terhadap rasa nata de mango dapat dilihat pada Tabel 4. Tabel 4 menunjukkan hasil uji organoleptik terhadap rasa nata de mango dimana pada perlakuan jenis mangga yang digunakan menunjukkan perbedaan yang nyata pada taraf signifikan 5\%. Rasa suatu bahan makana umumnya dipengaruhi oleh rasio gula dan asam yang terdapat dalam bahan makanan tersebut (Astawan, 1990).

Dari tabel 3 dapat juga dilihat bahwa nata de mango yang paling disukai adalah nata de mango dengan variasi perlakuan jenis mangga gedong dan arumanis dengan penilaian mangga gedong 4,45 (suka) dan mangga arumanis 4,25 (suka).

Panelis lebih menyukai nata dengan perlakuan jenis mangga gedong dan arumanis karena rasa nata lebih manis dan sedikit asam. Rasa nata juga dipengaruhi tekstur nata. Dimana nata dengan tekstur yang kenyal maka akan mempengaruhi kemampuan gula dari sirup masuk ke dalam nata.

\section{Sifat Organoleptik Tekstur Nata de Mango}

Tekstur merupakan sensasi tekanan yang dapat diamati dengan mulut ataupun perabaan dengan jari (Kartika, 1988). Hasil analisa data uji organoleptik terhadap tekstur nata de mango dapat dilihat pada tabel 5 .

Tabel 5 menjelaskan hasil uji organoleptik terhadap tekstur nata de manggo dimana pada perlakuan lima jenis mangga yang digunakan menunjukkan perbedaan yang nyata pada taraf signifikan 5\%. Hasil rerata uji organoleptik tekstur nata de mango berkisar antar 3,30 hingga 4,15 berada pada skala penilaian agak suka hingga suka. Tekstur nata de mango yang dihasilkan sesuai SNI No 01-4317-1996 yaitu normal, dimana tekstur nata de mango kenyal. Perlakuan jenis mangga gedong pada uji organoleptik tekstur dengan penilain 4,15 (suka) lebih disukai oleh panelis, sesuai dengan hasil analisa uji tekstur dimana tekstur nata de mango $73,00 \mathrm{~mm}$ yang menandakan tekstur kenyal. 
Tabel 4. Hasil Rata-rata Uji Organoleptik Rasa Nata de Mango

\begin{tabular}{cc}
\hline Jenis Varitas Mangga & Rasa Nata de Mango \\
\hline Arumanis & $\mathbf{4 , 2 5}$ \\
Gedong & $\mathbf{4 , 4 5}$ \\
Indramayu & $\mathbf{4 , 1 0}$ \\
Golek & $\mathbf{3 , 5 0}^{\mathbf{b}}$ \\
Kweni & $\mathbf{4 , 0 5}^{\mathbf{c}}$ \\
\hline
\end{tabular}

Ket : Angka yang diikuti oleh kode huruf yang berbeda menunjukkan adanya perbedaan yang nyata pada taraf signifikansi 5\%. Ket Skala : $1=$ sangat tidak suka; $2=$ tidak suka; $3=$ agak suka; $4=$ suka; $5=$ sangat suka

Tabel 5. Hasil Rata-Rata Uji Organoleptik Tekstur Nata de Mango

\begin{tabular}{|c|c|}
\hline Jenis Varitas Mangga & Tekstur Nata de Mango \\
\hline Harum Manis & $\mathbf{4 , 0 0}^{\mathbf{a}}$ \\
\hline Gedong & $\mathbf{4 , 1 5}^{\mathbf{a}}$ \\
\hline Indramayu & $\mathbf{3 , 8 5}^{\mathbf{b}}$ \\
\hline Golek & $\mathbf{3 , 8 0}^{\mathbf{b}}$ \\
\hline Kweni & $\mathbf{3 , 3 0}^{\mathbf{c}}$ \\
\hline
\end{tabular}

Ket : Angka yang diikuti oleh kode huruf yang berbeda menunjukkan adanya perbedaan yang nyata pada taraf signifikansi $5 \%$. Ket Skala : $1=$ sangat tidak suka; $2=$ tidak suka; $3=$ agak suka; $4=$ suka; $5=$ sangat suka

Tabel 5 menjelaskan hasil uji organoleptik terhadap tekstur nata de manggo dimana pada perlakuan lima jenis mangga yang digunakan menunjukkan perbedaan yang nyata pada taraf signifikan 5\%. Hasil rerata uji organoleptik tekstur nata de mango berkisar antar 3,30 hingga 4,15 berada pada skala penilaian agak suka hingga suka. Tekstur nata de mango yang dihasilkan sesuai SNI No 01-4317-1996 yaitu normal, dimana tekstur nata de mango kenyal. Perlakuan jenis mangga gedong pada uji organoleptik tekstur dengan penilain 4,15 (suka) lebih disukai oleh panelis, sesuai dengan hasil analisa uji tekstur dimana tekstur nata de mango $73,00 \mathrm{~mm}$ yang menandakan tekstur kenyal.

Menurut Masaoka et all (1993), nata yang baik berbentuk gel (seperti agaragar) dengan tekstur agak kenyal, putih dan transparan (menyerupai kolangkaling). Dengan kekenyalan yang sesuai teksturnya, maka semakin disukai oleh panelis.

\section{SIMPULAN}

Berdasarkan hasil analisa kadar serat pada nata de mango menunjukkan bahwa dari perlakuan jenis mangga yang digunakan dalam penggolahan nata de 
mango kandungan serat berkisar antara $1,43 \%$ hingga $2,35 \%$ sudah sesuai $\mathrm{SNI}$ No 01-4317-1996 dimana kandungan serat maksimum 4,5\%, analisa tekstur nata de mango bahwa dari perlakuan jenis magga yang digunakan dalam penggolahan nata de mango menunjukkan perbedaan yang nyata. Berdasarkan hasil uji organoleptik terhadap rasa, warna dan tekstur bahwa dari perlakuan jenis mangga yang digunakan menunjukan perbedaan yang nyata.

\section{DAFTAR PUSTAKA}

Anastasia, N., dan Eddy A. 2008. Mutu Nata de Seaweed dalam Berbagai Konsentrasi Sari Jeruk Nipis Prosiding Seminar Nasional Sains dan Teknologi-II 2008 Universitas Lampung, 17-18 November 2008

Astawan M. 1990. Teknologi Pengolahan Pangan Nabati Tepat Guna. Akademika Pressindo. Jakarta.

Astawan dan Mita Wijyuni. 1991. Teknologi Pengolahan Nabati Tepat Guna. Bogor: Akademi Pressindo

Astawan M. 2004. Nata De Coco Kaya Serat. Kompas Cyber Media Kesehatan: http://www.kompas.com/kesehata n/news/0402/25/213558 htm 24 Februari 2006.
Gennadios, A., McHugh, T. H., Weller, C. L., Krochta, J. M. (1994) Edible coating and film based on protein, dalam Edible Coating and Film to Improve Food Quality; Krochta, J. M., Baldwin, E. A., Nisperros-Carriedo, N., Eds., Technomic Pub., USA, 201278.

Heryawan, K. (2004) Pengaruh Konsentrasi Gula dan Lamanya Waktu Fermentasi terhadap Mutu Nata de Pina, Jurusan Teknologi Hasil Pertanian, Fakultas Pertanian Universitas Syiah Kuala, Darussalam, Banda Aceh.

Kartika, B., Hastuti, P dan Supartono, W. 1988. Pedoman Uji Inderawi Bahan Pangan. PAU Pangan dan Gizi-UGM, Yogyakarta.

Masaoka, C., Ohe, T., Sakato, N. (1993) Production of cellulose from glucose by acetobacter xylinum. Journal Fermentation Bioengineering, 75, 18-22.

SNI 01-4317-1996. Nata dalam Kemasan. Jakarta : Departemen Perindustrian

Soewedo, Hadiwiyoto. 1996. Panduan Praktikum Pengetahuan Bahan. Fakultas Teknologi Pertanian, UGM. Yogyakarta.

Susanti, L. 2006. Perbedaan Penggunaan Jenis Kulit Pisang Terhadap Kualitas Nata. (Skripsi). Semarang. Universitas Negeri Semarang.

Sutarminingsih, Ch. 2004. Peluang Usaha Nata de Coco. Yogyakarta : Kanisius 